\title{
THE REGIONALIZATION OF EUROPEAN SECURITY AND DEFENSE POLICIES IN THE MARITIME DOMAIN: THE BLACK SEA CASE
}

\author{
Siyana Lutzkanova \\ Nikola Vaptsarov Naval Academy (Bulgaria)
}

\begin{abstract}
The specific regional dynamics of maritime security environment in EU raise the question whether and to what extent the processes of "regionalization of security" need to be implemented within the principles of current CSDP (Common Security and Defense Policy) and European maritime security strategy. Joint civil-military concept of operations on regionalization of CSDP action in different regions like Saher Mali or Sahel Nigeria are good examples of tackling specific regional threats with individual regional approach based on the main strategic interests of the EU. The unification of policies based on international regulations in the maritime domain are examined in the context of the very specific regional aspects of the European national maritime spaces. Some examples of Black Sea maritime security issues are analyzed with the question to which extent basic assumptions of the current CSDP and European maritime security strategy are applicable to the challenges of the current security environment in this region. The levels of sustainability and resilience are connected to the processes of democracy development, some socio-demographic characteristics of the region and even cultural-civilizational aspects. Those assumptions are especially important in the context of state's resilience capabilities for preservations of basic state functions in times of crisis occurrence and crisis management. Another point is the possibility to use the regionalization security process as "window of opportunity" to set new agenda for possible mitigation of tensions between the Black Sea EU members and non EU-members in the region.

Keywords: regionalization of security; Black sea security; maritime risks and threats; containment and congagement strategies
\end{abstract}

\section{Introduction: theoretical framework}

The current global security environment has changed. The fragmentation of policies, the role of the leading political, economic and military powers and their interest projection in different regions, the growing asymmetry in socio-economic development and the decline of the real implementation of various political theo- 
ries such as the democratic peace theory or the global security regimes resulted in "regionalization of the security". This does not mean that common issues and efforts might become obsolete, this means that the policies, the approaches and the strategies have to adapt to some regional specifics that can even open different opportunities for solving security dilemmas.

The security environment in the Black Sea region is a good example of the process of "regionalization of security" in view of the fading relevance of the mentioned policies, both central in the international relations system after the Cold War. The relationship between political order and conflict levels was one of the most analyzed issues. The perception that the democratic states "bring peace" helped legitimize a number of US and UK policies towards common democratization of the world. The liberal theory of "democratic peace" favors the idea that the republican form of government calls for a "peaceful order" in international relations (Kant 2003; Doyle 1983) Several major research studies revealed some contradictions and definition problems in the democratic peace theory. It should be noted that the reason for the contradictory statistical results of the supporters of liberal theory of "democratic peace" is not a mistake in the statistical method but in the general lack of a unified definition of the terms "democracy" and "war" (Geis 2001; Layne 1994; Spiro 1994) Since the regimes' fall in Eastern Europe, different approaches and policies of democratization have led to different forms or even new forms of semi-democratic leadership. These countries in a transition process form a subcategory of the democratic regime, the so called "defective democracies". ${ }^{1)}$ Defective democracy is a kind of the rule of law related to the absence, limitation or non-observance of one or more criteria that characterize it (e.g. constitutional violations, inadequate respect for citizens' freedoms, unbalanced division of powers with concentration of power in one institution, violations of electoral law, violation of free access to information, etc.). For Black Sea countries, according to the common indicators for measuring democracy, Russia and Ukraine belong to this group. Georgia and Turkey are considered transitional democracies beyond the defective, Romania and Bulgaria most consolidated in the region. In this context, conclusions show less tendency of use of military power for the consolidated democracies compared to the first two groups. But the defragmented picture of democracy development process in the region shows higher tendencies to armed conflicts that regions with consolidated uniform democratic experience (Mansfield \& Snyder 1995). This means specifics in the politico-social attitudes to the use of military power in such regions.

Second example is the decline of the relevance of the global security regimes. The initial understanding for incorporating more regions in such political forms of the international relations system was connected to enhancing peace and security as well. It has become more and more difficult to attract and engage states in such regimes (e.g. Paris Agreement, the international regime on ban of chemical weapons a.o). Example from the Black Sea region is the termination of the 
INF-Treaty (Intermediate-Range Nuclear Forces Treaty) that was considered a strategic security regime in Europe. Erosion of global security regimes undermines balances of power that despite the new evolving threats continue to be the core principle of strategic deterrence.

NATO deployed a Rapid Response Force based in Eastern Europe, countries in the region increased their military budgets, increased patrols over land and sea in the Black and Baltic Sea. Russia annexed Crimea, modernized and enlarged the Black Sea Fleet based in Sevastopol, established control over the Crimean maritime spaces, deployed Iskander-M missile system with a firing range depending on the used rocket, from 500 to $2000 \mathrm{~km}$, launching missiles that can hit targets in the British Isles as well. In this way, the Black Sea area is covered by a large number of coastal anti-ship missiles, and complete control makes it relatively easy to destroy enemy navies in the Black Sea. Russia has developed, produced, tested and deployed a new intermediaterange missile known as the 9M729, or SSC-8. The 9M729 is mobile and easy to hide. It is capable of carrying nuclear warheads. It reduces warning times to minutes, lowering the threshold for nuclear conflict. And it can reach European capitals.

NATO conventional military capabilities are exclusively stronger and larger. Dominance of Russian naval capabilities compared to US is very unlikely. In this sense, given the nature of the use of tactical nuclear weapons in regional (local) conflicts and at close range, in this part, the Revised Russian Naval Doctrine 2030 reveals a completely new perspective on the capabilities of the Russian Navy, which should not be neglected. ${ }^{2}$ The possession of ultra-modern (nuclear) weapons means that the competition between the major powers is capable of causing global and / or regional disaster. It is difficult to predict the future of the INF-Treaty. Will this crisis be used by the North Atlantic partners to restart dialogue with Russia or will it be used for reciprocal action and deployment of the same force on European territory?

The logical consequence of these processes is the interruption and failure of all regional security initiatives. The decision in the early 1990 s to ensure security in Europe, not through new international organizations, but through existing Western NATO and the EU, at best gaining Russia status of associated partner, deepened the Ingroup-Outgroup dynamic and proved to be unsuccessful.

Another example in support of the regionalization dynamics: despite the conflict between Ukraine and Russia, EU sanctions, firm political tone and condemnation of Russian actions in Crimea and Eastern Ukraine, Western companies did not give up the business with the Russians and continued their energy cooperation with Russia-Germany, Austria, Hungary a.o. (Mainwaring 2014).

\section{Risks specifics in the black sea maritime domain}

\section{Hybrid and asymmetric risks}

The main characteristics of the current maritime security risks is their hybrid nature and their asymmetry. Most of the world's goods, services, communications, 
and cash flow chains are in private hands. Over $80 \%$ of the critical infrastructure of the western countries is owned or operated by the private sector. NATO is working closely with the private sector on logistics and communications, and this can have serious adverse effects during a crisis. Cybersecurity, diversification of energy supplies, offshore communications are the other potential targets of a hybrid attack. In 2017, a cyberattack against the Ukrainian government caused unprecedented damage to the Danish shipping company Maersk while it was paying its due fees in Ukraine online. Almost all of the company's operators worldwide have been shut down and even the company has completely lost control of its fleet management. Several other sectors have also suffered as Maersk's global supply chain has been virtually destroyed. More than $90 \%$ of intercontinental communication lines are underwater, again private. NATO and the European Union refer to these actions as "hybrid threats". As recently happened in both Crimea and the South China Sea, the hybrid approach is based on subtle but far-reaching and opportunistic methods that operate and fall into some kind of legal "Gray Zone", known as grey zone conflicts (Jordan 2020). The affected country has several options for reaction, but there is no sufficient legal reason to escalate the situation to an armed conflict.

\section{Lawfare}

"Lawfare" is a term used to describe the manipulation, misapplication or exploitation of laws to avoid attributing to hostile acts, engaging in destructive operations and shaping political and socio-economic conditions and justifying dubious military interventions. While Russia's "peaceful" annexation of the Crimean peninsula to "protect the rights of Russian-speaking people living abroad" is the most obvious regional case, it is by no means the only example. Russian peacekeepers are deployed on disputed territories in Georgia, Moldova and Ukraine. In the maritime domain, the lawfare tactics may include violation of the freedom of navigation, and impeaching the sovereign rights on national waters of allies and partners.

In the lawfare context are some tactics known as political interference in domestic matters or political disruption. This implies using direct or indirect ways to influence foreign domestic policies in particular direction, mainly weakening the democratic decision-making processes, the democratic establishments and key institutions and policies. This has a particular effect on states with some political, economic and social polarities, divisions etc.

\section{Disinformation campaigns}

This may include broad strategic disinformation campaigns, misrepresentation of international law, interference, media campaigns, undermining public trust, etc. In 2016 there was an incident where Russian frigate displayed an international signal for being restricted in her ability to maneuver, but then freely maneuvered in both course and speed as US naval ship changed course and speed. The interaction was assessed as unprofessional and deliberately used to show the American ship in bad light. 


\section{Economic and energy coercive tactics}

The approach concerns using the dominance of a country in energy or other domains to put pressure on other countries to act or re-act in a certain way in other socio-political spheres (Schultz 2001). The implementation of coercive strategies in the Black Sea region has increased since 2008. Russia uses coercive diplomacy strategies for preserving a strong political and military influence in the Eastern part of the region.

Coercive diplomacy has four main variables: pressure, tactics that create a sense of urgency, the specific consequences when "you do not obey", and the possible use of various incentives (George 1991). Based on these variables, George defines five types of coercive diplomacy: an ultimatum, a tacit ultimatum, a "try and see" approach, a "gradual slow tightening of the screw", and finally a "carrot and stick approach". The logical explanation for the success of coercive diplomacy lies in the belief that the adversary will act rationally. However, George concludes that the opponent's perception of the motivation and commitment of coercive power and the opponent's assessment of the trust and strength of his threat play the most important role in determining the success or failure of coercive strategy. The size and military power of a country are not an indicator of how big a role it will play in the region. Even small countries, especially those that have undergone a large-scale transformation process, can oppose large powers and this can lead to instability, tensions and military confrontation in the region. The events that took place after 2008 in the eastern part of the Black Sea region prove the interrelation between the stability of the regions, where even local conflict can escalate into large-scale confrontation and cause subsequent destabilizing effect for neighboring regions with serious consequences.

\section{Coercive military deterrence}

In recent times some coercive military actions appeared in the Black Sea. It is about demonstrating military capabilities through large-scale exercises, military presence, testing of new military systems, maneuvers near bordering countries, etc. The main point is the unclear intention for those actions. They appear in the so called "grey zone of conflict", aiming mainly to disorientate and mark traditional spheres of interest or show a regional power status. Such tactics are perceived to be part of a "grey zone conflict theory" and seem to appear in the current security environment quite often (Vgl. Jordan, 13). Offensive intelligence actions and other covert missions on foreign soil could be used to contribute such tactics.

To summarize, the abovementioned challenges appear to define the current security environment in the Black Sea region, including the maritime one. The non-violent characteristics of the disputes have the main aim to not cross the red lines, however, they require very strict and calculated mentoring and control because of their existence straight under the threshold of potential violent or armed escalation. 


\section{Impact on common security policies in the maritime domain: collective security in a regional sense}

The Black Sea and Eastern Mediterranean region is of particular importance for the European security, as it serves as a strategic maritime corridor in the south through the Four-Way Crossing of Europe with Eurasia, North Africa and the Middle East. The enhancement of Russia's military capabilities in the Crimea, the Black Sea and the Azov Sea, and the termination of the INF-Treaty, have changed NATO and EU concepts from "collective defense" and building expeditionary forces for action in remote regions to "territorial defense and NATO border protection". The continued presence of the NATO Response Force in the Baltic Sea, the tailored forward presence in the Black Sea region, are part of the response to protect the Eastern flank. The EU concept of "strategic autonomy" and the cooperation with the Allies in NATO are two sides of the same coin.

NATO and the EU are currently working together to strengthen cooperation in four areas: civil-military planning, cyber defense, information sharing and analysis, and coordinated strategic communications. Since 2016, they have agreed on 74 areas of deeper cooperation, 20 of which are related to countering hybrid threats. Building a bridge for sustainability between NATO, the EU and regional countries is not an easy task. EU should recognize that the Black Sea countries are front lines in the current hybrid threats strategies. Unfortunately, they may be considered as terrain for testing the EU and NATO determination to collective security. This thinking is collective security in a regional sense beyond only EU/NATO members.

Regional aspects should be included through possibilities of involvement of third countries. In 2016 in Bratislava, the EU Member States (EUMS) reiterated their intention to strengthen EU cooperation on external security and defense, the so called winter package on defense. Further operationalization and institutionalization is needed when it comes to regional security issues. It is a shared commitment between military, security and civilian actors including all the challenges of above mentioned strategies and tactics in a coercive manner or acting under the threshold of war.

Another principle related to the theoretical part of this study concerns the approach to the analysis of modern military-political policies, namely the combination of classical "hard" state interests, such as security and economic benefits, with moral attitudes and values - democracy and peace. Ignoring the last dimension is one of the main shortcomings in the current debates. Advocating these positions is difficult, they are highly emotionally charged, they reinforce lines and directions of behavior, compromises are difficult to achieve. It is therefore advisable to develop a promising policy strategy. This means that words and symbols carry more weight than conventional rationalism does. Speeches and statements must be carefully considered, especially in the current information age, when words sometimes play a stronger role than actions. Above all, orders, ultimatums, 
threats, verbal confrontations must be avoided at all costs, so that all stakeholders can build confidence in the intentions of consistent control and gradually make it their norm. New diplomatic tools are needed. The decision in the early 1990s to ensure security in Europe not through new international organizations, but through existing Western ones - NATO and the EU, where Russia received the status of an associate partner, deepened the Ingroup-Outgroup dynamics in the region (Dembinski et al. 2010).

One possible approach considers containment (neo-containment) and congagement (containment + engagement) strategies as political and diplomatic tools (Larsen 2020; Dembinski et al. 2014). EU's strong experiences in conflict resolution, conflict management, de-escalation, Petersburg missions lay the ground for future anticipation and inclusion of Russian, US and NATO interest in the broad Black Sea area. This means CSDP and NATO policies with strategic patience towards an actor that could not be ignored in the region. It would be a challenge when it comes to expanding military presence, the future of INF-treaty, as well as the deployment of further strategic weapon platforms that require immediate response in order to preserve the balances of power in the Black Sea. Neo-containment is open-ended, based on the assumption that economic weakness can trigger and revive the diplomatic dialogue bringing regional actors back on the table.

Congagement means negotiating a common normative order led by the principle "we are all in the same boat". Diplomacy seeks different instruments for that, in the Black Sea region the preservation of the strategic balances of power could be the right one. The damage of a potential escalation to an armed conflict is the worst case for everyone so this could be the base point for future actions. There are sufficient compensation mechanisms, such as achieving a sustainable balance of conventional forces between Russia and China, and others.

Another part of the congagement strategy is using spill-over effects. Despite their differences, before the crisis with Ukraine, the US and Russia had the opportunity to cooperate on issues of mutual interest in the Asia-Pacific region and succeeded in their bilateral relations. This opportunity was largely due to the fact that Russia was not present as a broad topic in the context of the Asia-Pacific strategy. In short, the United States and Russia have not developed the Asia-Pacific vector in their relations. And in the current geostrategic situation, it turns out to be a higher priority on the agenda of the two powers, before we can even talk about the normalization of relations in the European context of Crimea and Ukraine. This creates a possible spill-over effect that could be implemented in future European security and defense policies. Important by all means is the non-discrimination approach in every step of the process. Another prerequisite would be the strengthening of regional Black Sea synergies putting EU and NATO countries Romania, Bulgaria, partly Turkey on united front (Pop 2007). 


\section{Conclusions}

EU's CSDP has good experiences with regional security challenges. The diplomatic and military-political efforts to normalize the security environment in the Black Sea will be restored because it adheres to the basic principles of political and economic rationality. New diplomatic tools are needed due to the exhausted possibilities of the current international system to deal with the new challenges in the relations between key actors in the Black Sea. The neo-containment and congagement strategies offer a good basis for restarting the security regime in the region beginning with the rebuild of strategic balances of power. A change in the normative and value self-consciousness is under way. The imposition of western type democratic order, as the West understands it, is not adequate for Russia. Using spill-over effects and economic positives can contribute to the process led by the EU in the context of CSDP.

\section{NOTES}

1. http://www.systemicpeace.org/polity/polity4.htm, http://www.bti-project.de/btihome/, http://www.transparency.org/country

2. Fundamentals of the State Policy of the Russian Federation in the Field of Naval Operations for the Period Until 2030 (2017), available at: https://usnwc.edu/ Research-and-Wargaming/Research-Centers/Russia-Maritime-Studies-Institute

\section{REFERENCES}

Kant, I., 2003. Zumewigen Frieden, Einphilosophischer Entwurf. Stuttgart. Doyle, M., 1983. Kant, Legal Legacies, and Foreign Affairs: Part 1. Philosophy and Public affairs. 12(1), 205 - 335.

Geis, A., 2001. Diagnose: Doppelbefund-Ursache: ungeklaert? Die Kontroversen um den demokratischen Frieden. Politische Vierteljahreszeitschrift. 42(2), $282-298$.

Layne, C., 1994. Kant or Cant. The Myth of the Democratic Peace. International Security. 19(2), 5 - 49.

Spiro, D., 1994. The Insignificance of the Liberal Peace. International Security. 19(2), 50-86

Mansfield, E. \& Snyder, J., 1995. Democratization and the Danger of War. International Security. 20(1), 5 - 38

Mainwaring, J., 2014. Crimea: the Oil and Gas Story. Rigzone. https://www. rigzone.com/news/oil_gas/a/132554/crimea_the_oil_and_gas_story/

Jordan, J., 2020. International Competition Below the Threshold of War: Toward a Theory of Gray Zone Conflict. Journal of Strategic Security. 14(1), $1-24$. 
Schultz, K. A., 2001. Democracy and Coercive Diplomacy. Cambridge: Cambridge University Press, $8-10$.

George, A., 1991. Forceful Persuasion: Coercive Diplomacy as an Alternative to War. Washington, D.C.: United States Institute of Peace Press, Part II. Vgl. Jordan, 13

Dembinski, M., Schumacher, B., Spanger, H., 2010. Reset Revisited. Zur Programmierung europaischer Sicherheit. HSFK-Report 6. Frankfurt am Main.

Larsen, H., 2020. Neo-Containment: a Strategy toward Russia. Policy Perspectives. 8(1), 1 - 4 .

Dembinski, M., Schmidt, H., Spanger, H., 2014. Einhegung: die Ukraine, Russland und die europaeische Sicherheitsordnung. HSFK Report 3. Frankfurt am Main, 20 - 25

Pop, A., Manoleli, D., 2007. Towards a European strategy in the black sea area: The territorial cooperation. Strategy and Policy Studies (SPOS) (2007), 4. 